\title{
The punishment fits the crime
}

\author{
Everything's going to be all right.
}

\section{David Berreby}

Day 1: Come in, Tommy. Sit down. Don't be afraid. I have good news! Does your head hurt right now? Has it hurt any time since the doctor saw you? No, don't be scared. I have something wonderful to tell you: you're leaving us soon. Very soon. Thanks to the doctor, you're going to be smart!

Yes indeed, as smart as I am. Actually, you'll probably be smarter. (You always were, years ago, and you never let me forget it.)

Angry? Not at all. You have nothing to be afraid of? You'll see.

I think that's enough for now. I'll see you next week.

Day 8: Good morning, Tom. How's your head? Good. We don't expect those pains to last much longer. But now that you've matured a bit, I can be frank with you: we don't know much about what's happening to you, because you're one of the first people to be released from the programme. In fact, you're number one!

By now, I assume you understand that you're here because you did something wrong. No, no, sit down. Really, you must try to stay calm. It was years ago, and, as you've learned, it's all squared away now. Your debt is paid.

What? Well, you could say that, but I must say that's not a very positive way to look at things. You couldn't handle life on the outside, until a few days ago. Don't you remember? You thought and acted like a very small child, until we began the treatments.

I know! You couldn't help it, of course. That was your sentence: three year's severe impairment. Which I, on behalf of the duly constituted authorities, legal and medical, am pleased to say is ending.

No, I think that's enough for now.

Day 15: Well. That was quite an outburst, but I will try to be patient. Your position is unusual. One might say unique.

What do you want to know, then?

Yes, your sentence was entirely legal and approved only after expert review. No. No 'poisons' were used. What an idea! You were given the best treatments we have the vectors are absolutely safe, and our techniques here for somatic-genetic engineering are the best in the world. As you know. Or knew.

Of course it's not funny. What makes me

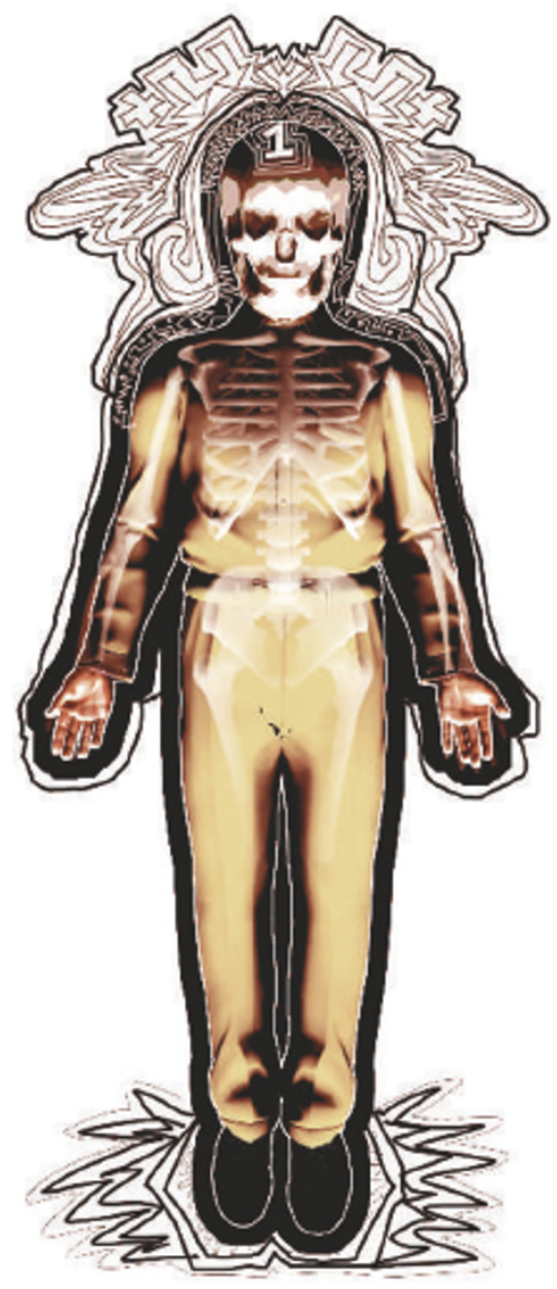

smile is pride - pride at the hard work of so many brilliant scientists, and the wisdom of our correctional reforms. Times were so different then. We thought the country was falling to pieces, as you may remember.

You don't? Ah, well.

The prisons were ever more crowded and expensive, even as genomic medicine was ever more successful and economical. It was only a matter of time before someone saw that techniques for gene therapy could also deliver gene punishment.

I was simply in the right place at the right time. I make no daim to brilliance or foresight.

And now, just a few years later, genetic correction is the law. In your case, you now produce a toxin that kills new-forming brain cells. Naturally, this has some effect on your mood, and your memory. And the expression of genes in your frontal cortex has been, shall we say, gently reorganized, so that your level of self-control has been approximately that of a normal three-year $\zeta$ old. Of course, you had to be cared for, and \$ so you came to live here with us. This is not a prison, but a facility for research and compassionate care. A facility I am proud to direct, I might add.

Oh, my. Your self-control doesn't seem to be coming back so well. That's all for today. Take him away.

Day 23: I must say my feelings are mixed. I am glad to see that you have recovered your abilities so completely: abilities which were once the envy of your colleagues, among whom, as you now recall, I number my humble self. But these antisocial remarks are very troubling.

Once again, I must remind you that you were sentenced after a lawful and constitutionally sound trial. And as sorry as you seem to feel for yourself now, I think, frankly, that you had it easy. Although the state no longer maintains a prison system, you have been provided with care and supervision. Most convicts are not. Do you know what the sentence for armed robbery in this state is today? Five years of lower-body paralysis, and good luck to you. Tax evasion? Two to five years' severe autism. Many families find it to be quite a burden. No, I'm sorry, I don't have to listen to such nonsense. Cruel and unusual, my foot! The High Court ruled against you: yes, against you. A leading geneticist campaigning against genetic punishment, confusing the moral and legal issues, making the people of this nation think that scientists weren't united in support of essential reforms. After passage of the Cellular Corrections Law of 2019, your activities were, in fact, criminal.

Ah, well. I'm afraid your disagreement doesn't matter much to me, Thomas. And I will have to ask you to set it aside.

No, that's not exactly right. It's not up to you. There is the little matter of probation. Your treatments here must continue: you will need a fresh injection every month for the rest of your life, and if you do not meet the conditions of your parole, such an injection will not be forthcoming.

From me. As director here, and as your friendly colleague of former days, I have taken it upon myself to monitor your progress.

I trust you will comport yourself with tact, then? Good. See you next month. David Berreby is a science writer and the author of Us and Them, a non-fiction book about group identity. He lives in New York City. 